\title{
Monitoring of the airborne pollen diversity in the urban area of san Salvador de Jujuy, Argentina
}

\begin{abstract}
The aim of this paper was monitoring the airborne pollen diversity in the San Salvador de Jujuy city during one year, in order to document its richness and seasonal dynamics, as well as to detect pollen grains with allergenic potential and to elaborate a pollen calendar. The sampling period lasted from August 2011 to July 2012. Airborne pollen monitoring was performed using a gravimetric Durham trap. A total of 56 pollen types were identified, of which $49 \%$ belong to native flora of Yungas, 32\% to exotic flora and $19 \%$ to undefined origin. Regarding to the distance of sources to the trap, $71 \%$ is located within a ratio of $2 \mathrm{~km}$ (Local), $24 \%$ coming from distance up to $5 \mathrm{~km}$ (Extralocal) and 5\% are sources placed more than $5 \mathrm{~km}$ (Regional). Eighteen pollen types with allergenic potential were detected, of which 15 are present in significant percentages. Pollen calendar shows the variation in the monthly relative frequency of the main pollen types.During the late winter, Morus, Alnus acuminata, Salix humboltiana and Pinus were identified as main emission sources. In spring, enhanced the richness of the local flora was observed. Exotic plants especially angiosperms (Fraxinus excelsior, Eucalyptus, Callistemon and Platanus acerifolia) dominated. There are also extra-local contributions of native species (Celtis, Anadenanthera colubrina and Parapiptadenia excelsa). During the summer, pollen richness declines and the NAP of herbs plants remains in high abundance (Poaceae, Amaranthaceae-Chenopodiaceae, Urticaceae) together with Casuarina cunninghamiana and Ulmus, but decreases progressively in autumn. In early winter, Cupressus predominates and regional contributions of A. acuminata are registered. Results revels the presence of allergenic pollen during the entire year. Considering the importance of public health, this study is a good reference to take criteria for selecting species on the planning of the plantation of urban trees in the city.
\end{abstract}

Keywords: allergy, gravimetric monitoring, jujuy, native flora, pollen calendar
Volume 2 Issue I - 2018

Torres GR, Pereira E de los A

Laboratory of Palynology, National University of Jujuy, Argentina

Correspondence: Gonzalo Torres, Laboratory of Palynology, Institute of Andean Ecoregions (CONICET-UNJu), Faculty of Agricultural Sciences, National University of Jujuy, Alberdi 47, CP Y4600DTA, Jujuy, Argentina, Tel (+54) 90388-422I550, Email gztorres@gmail.com, lab.palinologia@fca.unju.edu.ar

Received: December 19, 2017 | Published: February 08, 2018

\section{Introduction}

The diversity of the airborne pollen content of a city reflects its vegetation landscape at different spatial scales. Overall, it was estimated that the trapped pollen by a sampler placed about $15 \mathrm{~m}$ height records $50 \%$ of the pollen grains releasing above the canopy of the trees and it comes from distance $250 \mathrm{~m}$ or less, $45 \%$ coming from distance up to $5 \mathrm{~km}$ and only $5 \%$ coming from distance longer to $5 \mathrm{~km} .{ }^{1}$ Therefore, the main source of pollen is the local and extralocal flora. ${ }^{2}$ Within an urban area, local flora is composed by species forming part of the ornament in streets and green spaces, whereas the extra-local and regional flora depends of the phytogeographical context, where the city is located. In this sense, the plantation of the urban vegetation will be subject to the anthropic action (species cultivated or introduced involuntarily), that sometimes does not have an adequate planning and management, because alochthonous plants are planted that usually have components or toxic substances that represent a risk factor to public health. Likewise, the autochthonous or native vegetation of some regions can also constitute a source of natural risk to health and its impact on the local population deserves to be studied. ${ }^{3}$

Considering that exposure to pollen is one more way of interaction between humans and the environment, ${ }^{4}$ the monitoring of the airborne pollen in urban areas has great interest for ecological studies and environmental health. ${ }^{3,5,6}$ Aerobiological records provides information about plant phenology and changes in productivity as response to variations of weather conditions through the analysis of richness, abundance and seasonal dynamics of atmospheric pollen. ${ }^{7,8}$ In this way, it is possible to detect the begin, development and maximum stage of floral phases of the vegetation. ${ }^{6}$ However, sometimes, it is not straightforward detecting the final phase of the flowering, because the pollen grains can remain long time after they have been emitted into the atmosphere and the anthers have withered. ${ }^{9}$ All these situations are a function of the productivity, aerodynamic properties of the pollen grain and the meteorological conditions regulating its permanence in the air. Then, one of the aspects for studying the diversity and the different levels of pollen incidence into the atmosphere is the productivity of the flowers, which depends on the pollination strategy. Plants employing the wind as transfer agent (anemophilous) produce more pollen than those that depend on animals (zoophilous). ${ }^{10}$ For this reason, the dominant sources of atmospheric pollen belong to anemophilous plants, such as grasses, gymnosperms and some angiosperms. ${ }^{11}$

On the other hand, at the time of the an thesis, pollen grains of many species are covered by a sticky substance called "pollenkitt", which is secreted by the tapetalcells. ${ }^{12,13}$ The pollenkit is composed of lipids, carotenes, polysaccharides and glycoproteins in varying proportions. Particularly, glycoproteins cause allergy reactions (pollinosis), such as rhinitis, conjunctivitis and asthma in hypersensitive peoples. ${ }^{14}$ Frequently, these diseases appear during the pollination period and usually manifest as epidemic outbreaks. In 1930, Thommen ${ }^{15}$ formulated postulates to guide in the search for flora causing pollinosis: pollen must be anemophilous, produced in big quantities, to be light, small in size -between 10 and $40 \mu \mathrm{m}$ - and low specific weight. 
D'Amato et al. ${ }^{16}$ indicate that pollen grains having the aerodynamic size of $15 \mu \mathrm{m}$, cannot enter the lower areas of the respiratory tract, but larger ones can affect the conjunctive membranes, nasal and nasopharyngeal mucous. Therefore, the aerobiological record acquires utmost importance in the retrospective and prospective study of the etiological agent's dispersion of allergy diseases. ${ }^{8}$ In this context, constructing a pollen calendar generates retrospective information on the diversity and seasonal variation of surrounding pollen types in a city and helps to forecast their appearance in the atmosphere. This information is essential for the preventive therapeutic treatment of patients in a city.

Although volumetric sampling methods provide greater precision of pollen levels in the air and their temporal evolution, in different cities around of the world, the efficiency of gravimetric monitoring was demonstrated to obtain reliable information on the diversity of the airborne pollen content. ${ }^{17-20}$ In northwest Argentina, monitoring with gravimetric methodology showed that the native flora of Yungas Forest has a great representativeness in the atmospheric spectrum, ${ }^{21-23}$ but little is known about its allergenic potential. So far, aerobiological studies in San Salvador de Jujuy city are still scarce and only spans the spring season..$^{24}$ Therefore, it is important to extend the temporary record to characterize all seasons of the year. The aim of this paper was monitoring the diversity of the airborne pollen flora during one year in order to document its richness and seasonal dynamics, as well as to detect pollen grains with allergenic potential to elaborate a pollen calendar for the city of San Salvador de Jujuy.

\section{Materials and methods}

\section{Study area}

The city of San Salvador de Jujuy is the capital of Jujuy province, located to northwest Argentina (Figure 1). It lays in the temperate valleys region, between the confluence of the rivers Grande and XibiXibi ( $24^{\circ} 11^{\prime} \mathrm{S}, 65^{\circ} 17^{\prime} \mathrm{W}, 1259 \mathrm{~m}$ a.s.l). The surrounding landscape of the urban area is represented by mountain chains with several heights that are covered by the leafy native vegetation extending between the hills Los Perales and Alto del Tunalito, to northeast, and the hills Alto Padilla and De los Claros, to southwest. ${ }^{25,26}$ Relief has been modeled by the geomorphologic action of the river Grande, which given origin to three levels of fluvial terraces, being the third level (San Salvador terrace) the most recently formed and where the city is placed. ${ }^{27}$

The climate is characterized as subtropical with dry station. Summers are warm and rainy, the winters mild and dry. The annual mean temperature is $16.6^{\circ} \mathrm{C},,^{28}$ the precipitations are predominantly from orographic origin and reaches $826 \mathrm{~mm} / \mathrm{yr}$ concentrating in the warm epoch (December-March). ${ }^{29}$ The wind regime in the city is subjects to local variations since the circulation is strongly affected by the topography. Predominant winds are called valley-mountain breeze that circulate all the year. Another local wind is "Viento norte" originated by Föhen effect and transit the region during the autumnwinter months. In general terms, the mean velocity of the wind is $1.5 \mathrm{~m} / \mathrm{s}$ and the predominant directions are from $\mathrm{W}$ y SE. ${ }^{30}$

Since the phytogeographical viewpoint, the valley of Jujuy occupies the Yungas province. ${ }^{31}$ The ornamental plantation of the urban trees, both of the streets, squared and parks of the city, is composed by a diversity of exotic (the majority coming from north hemisphere) and native species whose flowering peak occur during the spring and summer according to observations of Díaz Iconomovich \& Rotman ${ }^{32}$ and Romeo \& Entrocassi. ${ }^{33}$ Phenological studies carried out by Brown ${ }^{34}$ also showed that more than $70 \%$ of the vegetation of Yungas flowering in spring season.
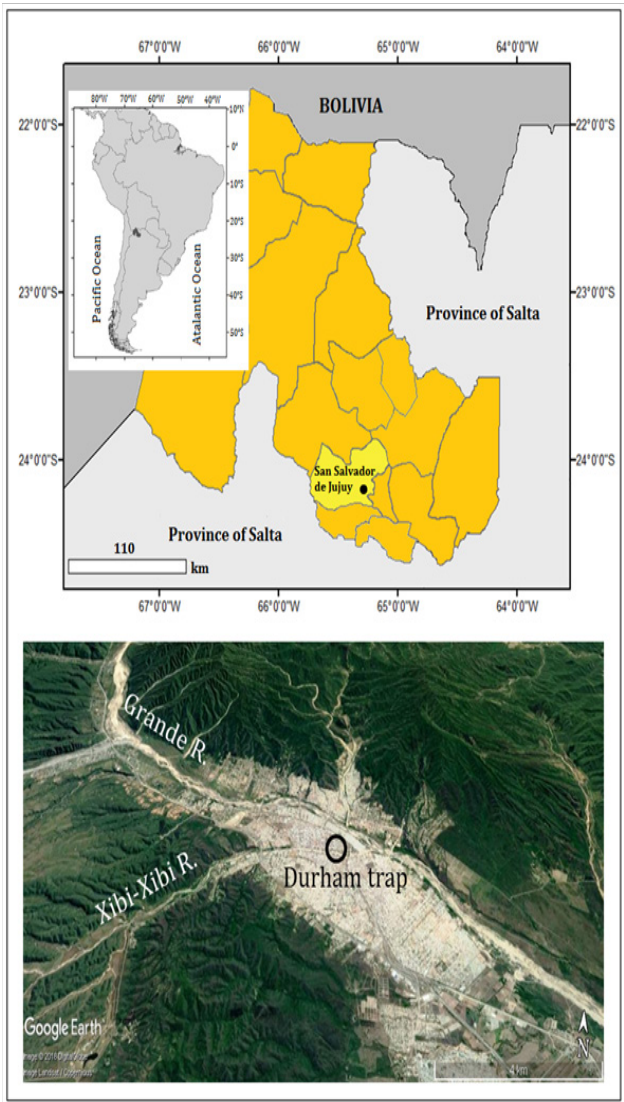

Figure I Location of the study area.

\section{Monitoring of airborne pollen}

The sampling period lasted from August 2011 to July 2012. Airborne pollen monitoring was performed using a Durham gravimetric trap. ${ }^{35}$ The sampler was placed $15 \mathrm{~m}$ above ground level on the roof of Faculty of Agricultural Sciences building. The frequency of slide replacement was weekly. For the assembly of the preparations, the Wodehouse ${ }^{36}$ technique was used. The count was performed with optical microscopes Zeiss ICS KF2 and Leica DM500, with 400X magnification. Pollen identification was carried out with the aid of a reference collection of the Laboratory of Palynology-National University of Jujuy (PAL-JUA) containing non acetholyzed pollen grains collected from the local flora and specific literature. ${ }^{37-39}$ Photographs of the pollen grains were taken with a Leica ICC50 camera incorporated into the microscope.

\section{Data analysis}

The identified pollen types were classified according the following criteria: A) Status of parent plant: natives or exotics in accordance with Zuloaga et al. ${ }^{40}$ B) Pollination strategy: anemophilous or zoophilous according Proctor et al. ${ }^{10}$ and Romeo \& Entrocassi, ${ }^{33} \mathrm{C}$ ) Parental source: arboreal pollen (AP) or non-arboreal pollen (NAP) including herbs and shrubs, and D) Distance of the source: Local, Extra-local and Regional according Prentice. ${ }^{41}$ The assignment of allergenic potential was based on bibliographic background. ${ }^{16,42,43}$ With obtained data, the pollen richness for each month was plotted and we compared the absolute abundance of trapped pollen of AP and 
NAP by station. Taking in account that the sampling period started in August, we divided it into: Late Winter (August-September 2011), spring (October-December 2011), summer (January-March 2012) and Early Winter (June-July2012). For plotting the pollen calendar, a diagram of monthly relative frequencies (expressed in percentages) was constructed using Pan Plot v11.04 software. ${ }^{44}$ Pollen types present in less than $3 \%$ were excluded.

Table I List of identified pollen types

\begin{tabular}{|c|c|c|c|c|c|c|}
\hline Pollen type & $\begin{array}{l}\text { Status of the } \\
\text { parent plant }\end{array}$ & $\begin{array}{l}\text { Pollination } \\
\text { strategy }\end{array}$ & Source & $\begin{array}{l}\text { Spatial } \\
\text { distribution }\end{array}$ & $\begin{array}{l}\text { Allergenic } \\
\text { potential }\end{array}$ & $\begin{array}{l}\text { Total } \\
\text { abundance }\end{array}$ \\
\hline Acacia & $\mathrm{N}$ & $\varepsilon$ & $\mathrm{AP}$ & L-Ex & & 29 \\
\hline Acer negundo & $E$ & $\alpha$ & $\mathrm{AP}$ & $\mathrm{L}$ & ○ & 243 \\
\hline Allophylus edulis & $\mathrm{N}$ & $\varepsilon$ & $\mathrm{AP}$ & Ex & & 60 \\
\hline Alnus acuminata & $\mathrm{N}$ & $\alpha$ & $\mathrm{AP}$ & $\mathrm{R}$ & & 1175 \\
\hline $\begin{array}{l}\text { Amaranthaceae/ } \\
\text { Chenopodiaceae }\end{array}$ & $\mathrm{N}$ & $-\alpha$ & NAP & $\mathrm{L}$ & $\bullet$ & 420 \\
\hline $\begin{array}{l}\text { Anadenanthera } \\
\text { colubrina }\end{array}$ & $N$ & $\alpha$ & AP & L-Ex & & 631 \\
\hline Apiaceae & I & $\varepsilon$ & NAP & $\mathrm{L}$ & & $4 I$ \\
\hline Asteraceae & I & $\varepsilon$ & NAP & L-Ex & & $17 \mid$ \\
\hline Blepharocalyx & $\mathrm{N}$ & $\varepsilon$ & $\mathrm{AP}$ & Ex & & 2 \\
\hline Boraginaceae & I & $\varepsilon$ & NAP & $\mathrm{L}$ & & 66 \\
\hline Caesalpinia & $\mathrm{N}$ & $\varepsilon$ & $\mathrm{AP}$ & $\mathrm{L}$ & & 5 \\
\hline Callistemon & $E$ & $\varepsilon$ & $\mathrm{AP}$ & $\mathrm{L}$ & $\bullet$ & 3176 \\
\hline $\begin{array}{l}\text { Casuarina } \\
\text { cunninghamiana }\end{array}$ & $E$ & $\alpha$ & $\mathrm{AP}$ & $\mathrm{L}$ & ○ & 1294 \\
\hline Celtis & $\mathrm{N}$ & $\alpha$ & $\mathrm{AP}$ & Ex-R & ○ & 4076 \\
\hline $\begin{array}{l}\text { Crinodendron } \\
\text { tucumanum }\end{array}$ & $\mathrm{N}$ & $\varepsilon$ & $\mathrm{AP}$ & Ex & & 7 \\
\hline Cupressus & $E$ & $\alpha$ & AP & $\mathrm{L}$ & $\bullet$ & 1453 \\
\hline Cyperaceae & I & $\alpha$ & NAP & $\mathrm{L}$ & & 4 \\
\hline Ericaceae & I & $\alpha$ & NAP & $\mathrm{L}$ & & 3 \\
\hline Eucalyptus & $E$ & $\varepsilon$ & AP & $\mathrm{L}$ & $\bullet$ & 895 \\
\hline Eupatorium & I & $\varepsilon$ & NAP & $\mathrm{L}$ & & 273 \\
\hline Fabaceae & I & $\varepsilon$ & NAP & $\mathrm{L}$ & & 154 \\
\hline Fraxinus excelsior & $E$ & $\alpha$ & AP & $\mathrm{L}$ & 0 & 2045 \\
\hline Ginkgo biloba & $E$ & $\alpha$ & AP & $\mathrm{L}$ & & 19 \\
\hline Gomphrena & I & $\varepsilon$ & NAP & $\mathrm{L}$ & & 35 \\
\hline Grevillea robusta & $E$ & $\varepsilon$ & AP & $\mathrm{L}$ & & 104 \\
\hline Handroanthus & $\mathrm{N}$ & $\varepsilon$ & AP & $\mathrm{L}$ & & 3 \\
\hline Heteropterys & $\mathrm{N}$ & $\varepsilon$ & NAP & L-Ex & & 8 \\
\hline Juglas australis & $\mathrm{N}$ & $\alpha$ & AP & $\mathrm{R}$ & & 503 \\
\hline Justicia & $\mathrm{N}$ & $\varepsilon$ & AP & Ex & & 3 \\
\hline Lamiaceae & $\mathrm{N}$ & $\varepsilon$ & NAP & $\mathrm{L}$ & & 34 \\
\hline Loranthaceae & I & $\varepsilon$ & NAP & $\mathrm{L}$ & & 3 \\
\hline Melia azedarach & $\mathrm{E}$ & & $A P$ & $\mathrm{~L}$ & & 3 \\
\hline
\end{tabular}

\section{Results and discussion}

A total of 56 pollen types were identified during the sampling period (Table 1), of which $49 \%$ belonged to native flora, $32 \%$ to exotic flora and 19\% to undefined origin (Figure 2a). Regarding to the distance of sources to the Durham trap, $71 \%$ is located within a ratio of $2 \mathrm{~km}$ (Local), $24 \%$ coming from distance up to $5 \mathrm{~km}$ (Extra-local) and $5 \%$ are sources placed more than $5 \mathrm{~km}$ (Regional) (Figure $2 \mathrm{~b}$ ). 


\begin{tabular}{|c|c|c|c|c|c|c|}
\hline Pollen type & $\begin{array}{l}\text { Status of the } \\
\text { parent plant }\end{array}$ & $\begin{array}{l}\text { Pollination } \\
\text { strategy }\end{array}$ & Source & $\begin{array}{l}\text { Spatial } \\
\text { distribution }\end{array}$ & $\begin{array}{l}\text { Allergenic } \\
\text { potential }\end{array}$ & $\begin{array}{l}\text { Total } \\
\text { abundance }\end{array}$ \\
\hline Mimosa & $\mathrm{N}$ & $\varepsilon$ & NAP & L & & 6 \\
\hline Myrtaceae & 1 & $\varepsilon$ & AP & L-Ex & & 94 \\
\hline Morus & $\mathrm{E}$ & $\alpha$ & AP & L & • & $|82|$ \\
\hline $\begin{array}{l}\text { Parapiptadenia } \\
\text { excelsa }\end{array}$ & $\mathrm{N}$ & $\alpha$ & $A P$ & Ex & & 355 \\
\hline Peltophorum dubium & $\mathrm{E}$ & $\varepsilon$ & AP & L & & 51 \\
\hline Persea americana & $\mathrm{E}$ & $\varepsilon$ & AP & L & & 2 \\
\hline $\begin{array}{l}\text { Phyllostylon } \\
\text { rhamnoides }\end{array}$ & $\mathrm{N}$ & $\alpha$ & $A P$ & Ex & & 55 \\
\hline Pinus & E & $\alpha$ & AP & L & - & 908 \\
\hline Platanus acerifolia & $E$ & $\alpha$ & AP & L & $\bullet$ & 472 \\
\hline Poaceae & 1 & $\alpha$ & NAP & L & $\bullet$ & 699 \\
\hline Polylepis & $\mathrm{N}$ & $\alpha$ & AP & L & & 57 \\
\hline Populus & $\mathrm{E}$ & $\alpha$ & AP & L & • & 14 \\
\hline Prunus & $\mathrm{N}$ & $\varepsilon$ & AP & L-Ex & & 13 \\
\hline Quercus & $\mathrm{E}$ & $\alpha$ & AP & L & • & 191 \\
\hline Rumex & $\mathrm{E}$ & $\alpha$ & NAP & L & • & 383 \\
\hline Salix humblodtiana & $\mathrm{N}$ & $\alpha$ & AP & L & $\bullet$ & 1567 \\
\hline Sapium & $\mathrm{N}$ & $\varepsilon^{-\alpha}$ & AP & L-Ex & & 26 \\
\hline Sebastiania brasiliensis & $\mathrm{N}$ & $\varepsilon$ & $A P$ & Ex & & 2 \\
\hline Seiba speciosa & $\mathrm{N}$ & $\varepsilon$ & AP & L & & 4 \\
\hline Tecoma stans & $\mathrm{N}$ & $\varepsilon$ & NAP & L & & 49 \\
\hline Ulmus & $\mathrm{E}$ & $\alpha$ & AP & L & $\bullet$ & 264 \\
\hline Urticaceae & $\mathrm{N}$ & $\alpha$ & NAP & L-Ex & $\bullet$ & 811 \\
\hline Viguiera & $\mathrm{N}$ & $\varepsilon$ & NAP & L & & 165 \\
\hline Zanthoxylum coco & $\mathrm{N}$ & $\varepsilon$ & AP & Ex & & 280 \\
\hline
\end{tabular}

N, Native; E, Exotic; I, Undefined Origin; $\alpha$,Anemophilous; $\varepsilon$, Zoophilous;AP,Arboreal Pollen; NAP, Non-Arboreal Pollen; L, Local; Ex, Extra-Local; R, Regional

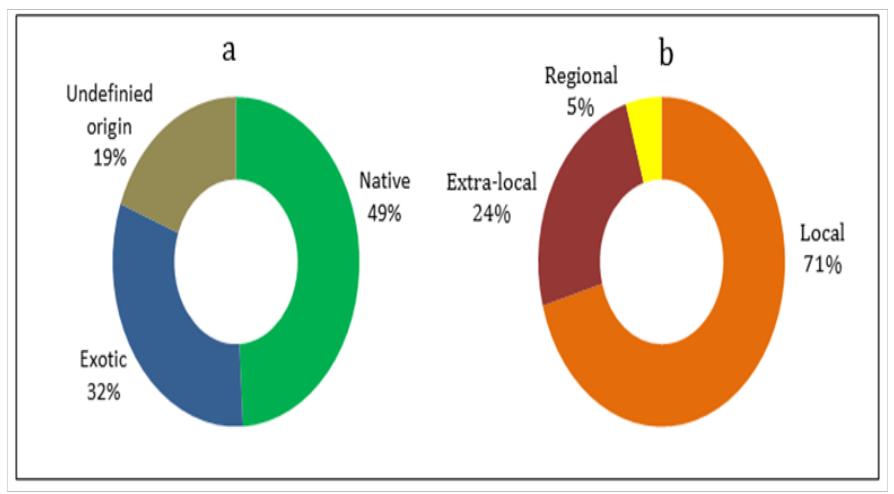

Figure 2 Composition of the pollen content according to: a) Status source; b) Spatial scale.

The analysis of the monthly variation of total pollen richness shows progressive increase from August to reaches the maximum amount of pollen types in October (46) which coincides with the maximum richness of AP (31) and NAP (15). From October, total pollen richness decreased to a minimum in January and April (16), likewise AP (8)
(Figure 3). The lowest NAP richness was recorded in August (6). Seasonal distribution of absolute abundance of AP and NAP (Figure 4) showed that the late winter recorded the maximum incidence of AP (10918 grains), being September the month of greatest contribution (AP: 7926grains). In spring, the maximum of NAP was recorded (745grains), being October the month of greatest contribution (470grains). By contrast, the lower incidence was recorded in autumn (310grains) particularly in April (50grains), in turn coincides with the minimum of AP (17grains) and NAP (33grains).

A noticeable change in monthly pollen composition was observed during the sampling period. Pollen calendar (Figure 5) shows the variation in the monthly relative frequency of the main pollen types. In the late winter, the maximum contributions of anemophilous taxa were registered, both from the exotic flora, Morus (29.4\%), as well as native flora, Alnus acuminata (19.4\%), Salix humboltiana $(16.8 \%)$ and Celtis (14.3\%). During the spring, the percentages of Celtis $(24.4 \%)$, Callistemon (24.4\%), Anadenathera colubrina (21.2\%), Eucalyptus (12.2\%) Fraxinus excelsior (20.9\%), Platanus acerifolia (3.2\%) and Pinus (7.8\%) increased. In summer, high contents of NAP composed by Poaceae $(38.8 \%)$, Urticaceae $(25.5 \%)$ and Amaranthaceae- 
Chenopodiaceae (14.3\%), stand out, while the contribution of AP is composed by Casuarina cunnighamiana (69.5\%), Ulmus $(26.3 \%)$ and Myrtaceae (11.4\%). In the autumn months, the percentages of NAP are kept high and AP decreases notably. For early winter, the dominant content of Cupressus (64.2\%), Alnus acuminata (17.5\%) and Pinus (5.1\%) were observed. Of all recorded pollen grains, 18 with recognized allergenic potential were detected, of which 15 are present in significant percentages (Figure 6).

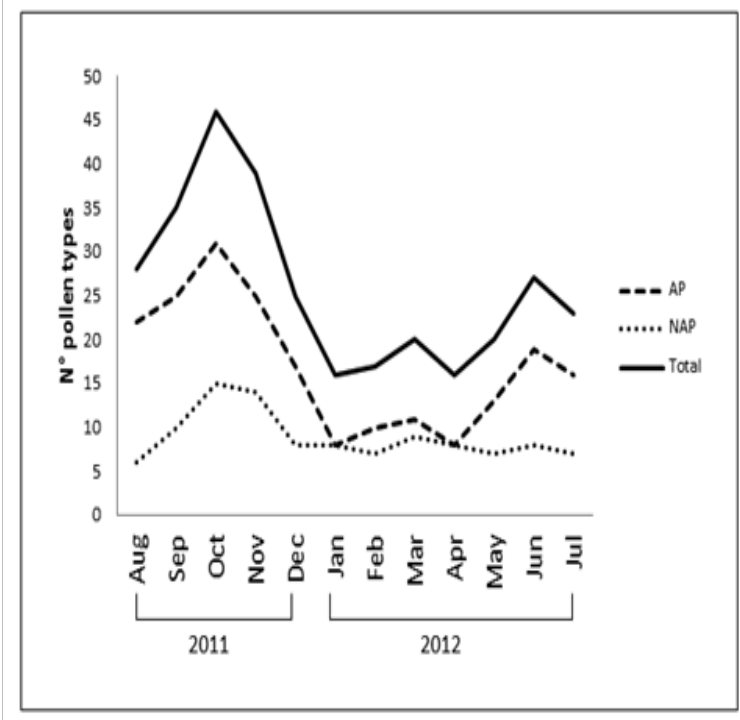

Figure 3 Monthly variation of the pollen richness.

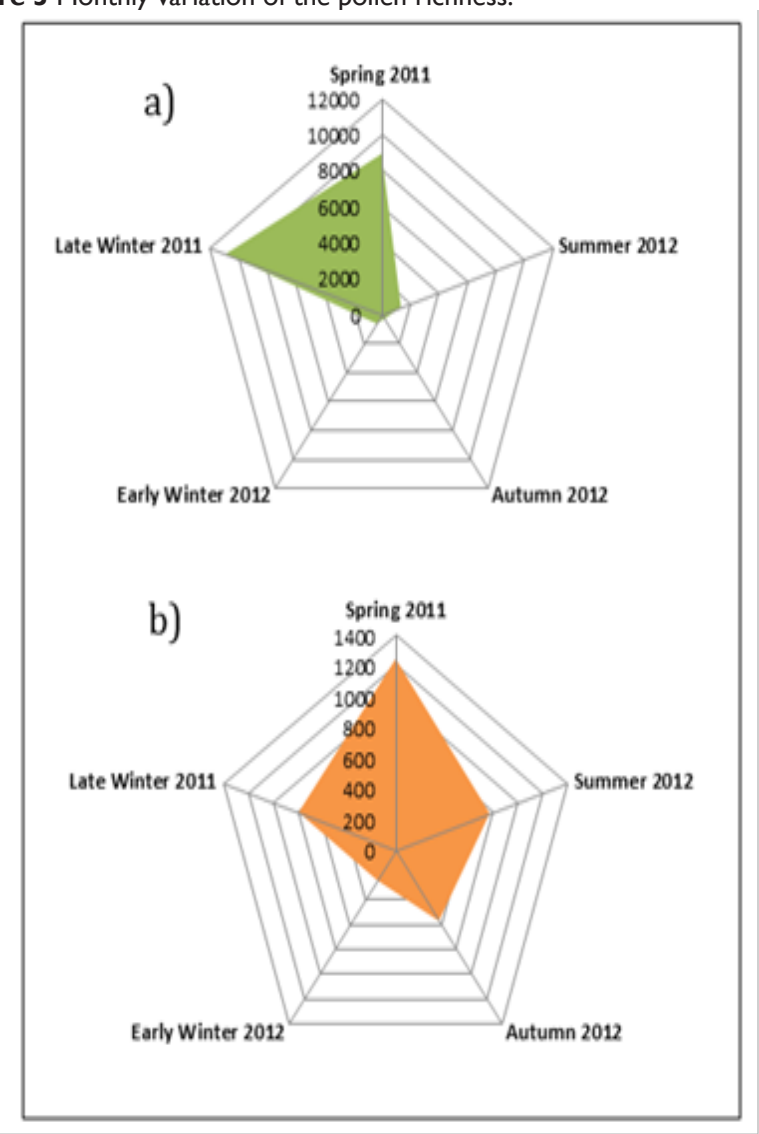

Figure 4 Absolute abundance of trapped pollen by season. a) AP and b) NAP.

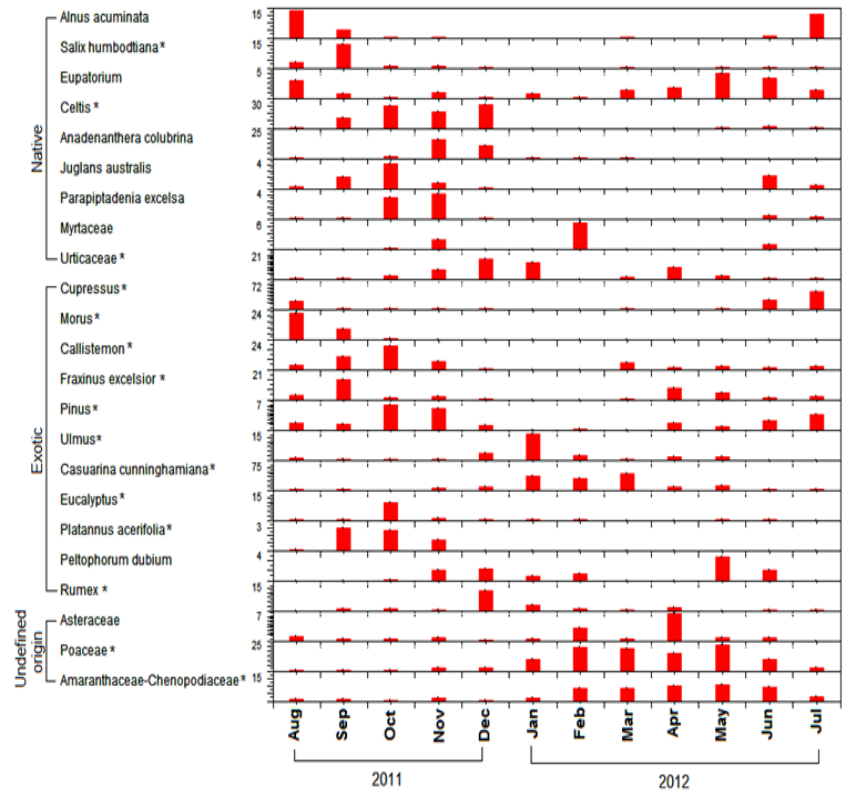

*,Allergenic Potential

Figure 5 Pollen calendar for the year 20II-20I2

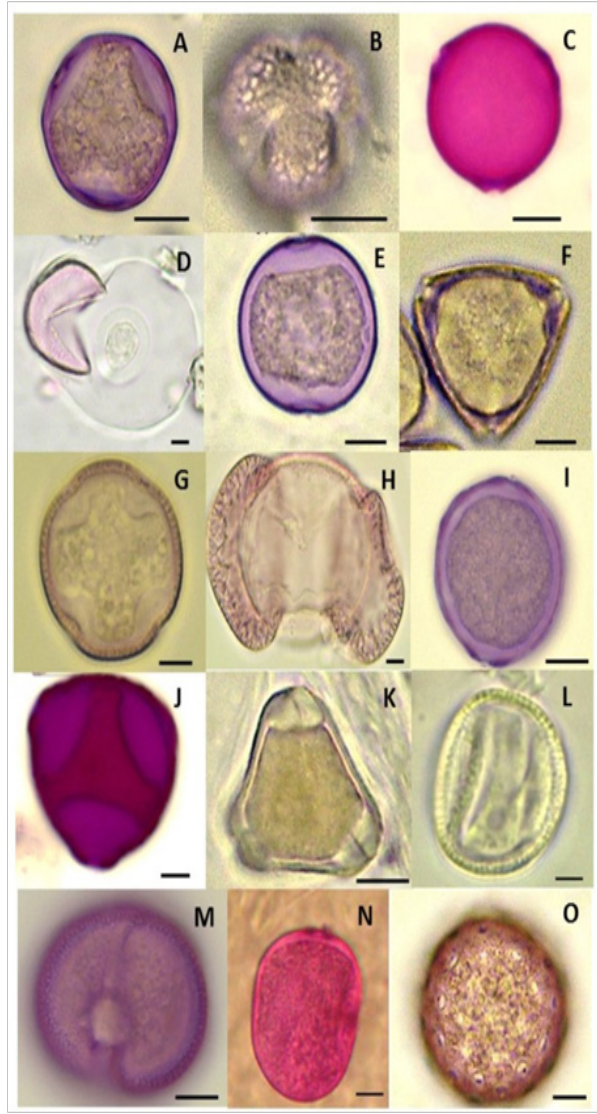

Figure 6 Pollen types with allergenic potential. Native flora: A) Celtis; B) Salix humblodtiana; C) Urticaceae; Exotic flora: D) Cupressus; E) Morus; F) Callistemon; G) Fraxinus excelsior; H) Pinus; I) Ulmus; J) Casuarina; cunninghamiana; K) Eucalyptus; L) Platanus acerifolia; M) Rumex; Undefined origin: N) Poaceae; O) Amaranthaceae-Chenopodiaceae; Scale bar correspond to $10 \mu \mathrm{m}$. 
The diversity of the airborne pollen in the San Salvador de Jujuy city reflects the influence of local, extra local and regional flora. Local flora presents greater richness and is integrated by ornamental species of urban trees, most exotic species. ${ }^{32,33}$ The extra local and regional floras are represented by the contribution of native species of the Yungas, ${ }^{31}$ the former by Lower Montane Forest and the later by the Upper Montane Forest. The sampling proves that the best represented sources were those that are close to the trap. ${ }^{1,2}$ It was also found that regardless of their spatial distribution, the highest pollen emission into the atmosphere came from the anemophilous plants. ${ }^{11}$ For this reason, the month of greatest richness (October) does not coincide with the month of maximum incidence (September), since in the late winter, there are only anemophilous plants, instead in spring there are also contributions of zoophilous plants. This is because; it is the main flowering season of the plants with this pollination strategy. ${ }^{10,34}$ These results were comparable with previous samplings in the city. ${ }^{24}$ In other cities of northwestern Argentina, similar results were obtained. ${ }^{21-23}$ In this context, the duration of the pollination period of vegetation ${ }^{6}$ and the months of maximum incidence of pollen in the city's atmosphere can be estimated.

On the other hand, in this study, 18 pollen types that constitute a risk to public health were detected. Most belong to the exotic flora, but elements of the native flora are also highlighted as Salix humboltiana, Urticaceeae and Celtis. In addition, A. acuminata and $J$. australis present properties to be considered as allergenic agents, according to Thommen's postulates. ${ }^{15}$ Hence, there is a need to conduct sensitivity studies to determine the allergenic degree of these pollen types.

The knowledge about seasonal fluctuations in airborne pollen is essential for effective diagnosis and treatment of allergy. ${ }^{3,8}$ Although, it is important to note some aspects in reading the pollen calendars. Sometimes, errors of interpretation and/or discordance with the information occur, because there is not always a positive correlation between exposure during the pollination period and allergy symptoms. ${ }^{14}$ This lack of correlation is due to different causes, for example, the reaction of the immune system to glycoproteins of pollen kit is very variable among patients, and many people have allergies to plants that bloom simultaneously, the response of the membranes (nasal, bronchial and conjunctival) increases throughout the season due to the effect called "priming". ${ }^{45}$ The effect consists of the progressive decrease in the intensity of the exposure to the allergenic agent necessary to trigger an inflammatory response, so that as the season progresses a less intense exposure to the allergen is necessary for the symptoms to appear. Then, understanding these topics are most useful to both the allergologist who can adopt diagnostic measures, and the patients who can correlate their symptoms with the periods when allergenic pollen is present in the atmosphere.

\section{Conclusion}

This study extends the knowledge about the diversity of airborne pollen in the San Salvador de Jujuy city, since it represents the first annual monitoring. The aerobiological record allows characterizing qualitatively the seasonal dynamics of atmospheric pollen content During the late winter, Morus, S. humboldtiana, A. alcuminata and Pinus were identified as main emission sources. Inspring, enhanced in the richness of the local flora were observed. Exotic plants especially angiosperms (F. excelsior, Eucalyptus, Callistemon and P. acerifolia) dominated. There were also extra-local contributions of native species (Celtis, A. colubrina and P. excelsa) in the same station. During the summer, the pollen richness declines and the NAP of herbs plants remain in high abundance (Poaceae, Amaranthaceae-Chenopodiaceae, Urticaceae) together with $C$. cunninghamiana and Ulmus, but, subsequently decrease progressively in autumn. In early winter, gymnosperms (Cupressus) predominate and regional contributions of native species of the Yungas (A. acuminata) are registered. It is emphasized that the native flora are present in significant percentages and a marked seasonality can be observed in the phenology of the species.

Results reveal the presence of allergenic pollen from different taxa during the entire year. The greatest richness is concentrated in spring and in late winter, the highest absolute abundance of pollen grains was found, composed of high productivity species. Although, it is still unknown, if Yungas Forest species (A. acuminata and $J$. australis) cause allergy, it is probably which they have an impact on the population, given the characteristics of its pollen grains. Hence, winter could also be considered as a risk period by pollinosis in the city due to the high exposure to pollen of Cupressus and native flora. Considering the importance of public health, the results of the study are a good reference to take criteria for selecting species on the planning of the plantation of urban trees in the city.

\section{Acknowledgements}

This study was possible thanks to funding provided by Faculty of Agricultural Sciences, National University of Jujuy. We also wish to thank for the support, counseling and facilities from Laboratory of Palynology offered by Dr. Liliana Lupo. To Fabio Flores and Magalí Méndez for the help in the sampling.

\section{Conflict of interest}

The authors declare that there is no conflict of interests regarding the publication of this paper.

\section{References}

1. Tauber H. Investigations of aerial pollen transport in a forested area [Gribskov, Sealand, Denmark]. Gioenia Sci Nat 1977;19(328):211-236.

2. Halwagy MH. Concentration of airborne pollen at three sites in Kuwait. Grana. 1988;27(1):53-62.

3. Olabuenaga S, Bianchi M, Vacchino M, et al. Pollen and pollinosis in San Carlos de Bariloche. Saberes. 2007;4(6):42-47.

4. González-Minero JF, Cerbino J. Importance of pollen counts in the air, an example. Rev salud ambient. 2016;16(1):43-51.

5. Main CE. Aerobiological, ecological, and health linkages. Environment international. 2003;29(2-3):347-349.

6. Nitiu D. Study of atmospheric pollen and its revelation with local vegetation. The Silver Argentina. Acta Botánica Malacitana. 2009;34:1-11.

7. Newnham RM. Monitoring biogeographical response to climate change: The potential role of aeropalynology. Aerobiologia. 1999;15(2):87-94.

8. Latorre F, Bianchi MM. Relationship between aeropolen and arborea vegetation in Mar del Plata (Argentina). Polen. 1997;8:43-59.

9. O'Rourke MK. Pollen reentrainment: contributions to the pollen rain in an arid environment. Grana. 1990;29(2):147-152.

10. Proctor M, Yeo P, Lack A. The natural history of pollination. Timber Press, Portland, Oregon, USA; 1996. p. 479.

11. Lacey ME, West JS. The air spora. A manual for catching and identifying airborne biological particles. Springer Softcover. 2006. p. 156.

12. Knoll F. About pollen kitten and pollination type. $Z$ Bot. 1930;23:610-675 
13. Pacini E, Hesse M. Pollenkitt - its composition, forms and functions. Flora. 2005;200(5):399-415.

14. Valero-Santiago AL, Picado-Vallés C. Polinosis. In: Valero-Santiago AL, Candahía-García A, editors. Polinosis Polen y Alergia. MRA ediciones, Spain; 2002. p. 158.

15. Thommen AA. Hayfever: the spring type. Med J and Rec. 1930;131:496

16. D’Amato G, Cecchi L, Bonini S, et al. Allergenic pollen and pollen allergy in Europe. Allergy. 2007;62(9):976-990

17. Hoffmann A, Riveros F, Araya S, et al. Identification and counting of atmospheric pollen in central Chile (1976-1977). Rev Med de Chile. 1978;106:595-600.

18. Piotrowska K, Weryszko-Chmielewska E. Pollen count of selected taxa in the atmosphere of lublin using two monitoring methods. Ann Agric Environ Med. 2003;10(1):79-85.

19. González O, Fuentes Y, Rodríguez R, et al. Pollen calendar in a region of Havana City. Vacci Monitor. 2009;18(3):1-4.

20. Benedetti GM, Sastre BS, Campo AM. Pollen calendar of potentially allergenic species and its relation with meteorological parameters in villa ventana, province of buenos aires. Boletín geográfico. 2014;36:85-99.

21. García ME. Aeropalinology of Santiago del Estero I. Arch. Arg. of Allergy and Immune. Clinic. 1990;22:6-12.

22. García ME. Aeropalinology of Santiago del Estero II. Arch. Arg. Of Allergy and Immunity. Clinic. 1993;24:76-78.

23. García ME. Aeropalinology of Salta. Summary published in the minutes of the XI Argentine Symposium on Paleobotany and Palynology. Mar del Plata, Argentina; 1994.

24. Torres GR, Flores FF. Atmospheric pollen report during the spring season of 2007 in the city of San Salvador de Jujuy, Argentina. Rev Mus Argentino Cienc Nat. 2013;15(2):175-182.

25. Paleari A. Juvenian to ponymic dictionary. 1st edn. Printing of the state of the province of Jujuy. San Salvador de Jujuy, Argentina; 1981. p. 285.

26. Kulemeyer JA. Salvage and enhancement of the archaeological site of Bajo La Viña. Report, Inedit. 1998.

27. Alcalde JA, Solís N, Kulemeyer JJ. Geomorphological map of San Salvador de Jujuy, Jujuy, Argentina. Cuadernos. 1992;4:183-186.

28. Braun Wilke R, Santos E, Picchetti L, et al. Letter of environmental aptitude of the province of Jujuy. Art-Science, Argentina; 2013. p. 245.

29. Bianchi A, Yañez C, Acuña L. Monthly rainfall database of the Argentine Northwest. EEA, Salta-Jujuy, Argentina; 2005. p. 41.

30. Buitrago LG. The climate of the Province of Jujuy. Chair of Climatology and Agricultural Phenology. 2nd ed. Jujuy, Argentina; 1999. p. 39.
31. Cabrera A. Phytogeographic provinces of Argentina. Encyclopedia of Agriculture and Gardening Argentina. Buenos Aires, Argentina; 1976. p. 85 .

32. Díaz Iconomovich SF, Rotman AD. Urban trees of San Salvador de Jujuy. Trees of the parks and squares of the macrocenter. 1st edn. Cd-rom, Jujuy, Argentina; 2008.

33. Romeo AR, Entrocassi GS. The trees of the city of San Salvador de Jujuy. Province of Jujuy, Jujuy, Argentina; 2012. p. 186.

34. Brown AD. Phenology and fallen leaf litter in the mountain jungles of El Rey National Park, Argentina. In: Brown AD, Grau HR, editors. Research, Conservation and Development in subtropical mountain forests. Argentina; 1995. p. 93-102.

35. Durham O. The volumetric incidence of atmospheric allergens: IV. A proposed standard method of gravity sampling, counting, and volumetric interpolation of results. J Allergy. 1946;17(2):79-86.

36. Woodehouse RP. Pollen grains. McGraw-Hill Book Company, New York, USA; 1935.

37. Heusser CJ. Pollen and Spores of Chile. The University of Arizona Press. Tucson, Arizona; 1971. p. 167.

38. Markgraf V, Dantoni H. Pollen Flora of Argentina. The University of Arizona Press. Tucson, Arizona; 1978. p. 208.

39. Grant Smith E. Sampling and identifying allergenic pollens and molds. An illustrated identification manual for air samplers Blewstone Press, San Antonio, Texas, USA; 1990. p. 195.

40. Zuloaga FO, Morrone O, Belgrano MJ. Catálogo de las Plantas Vasculares del Cono Sur. Monographs in Systematic Botany from the Missouri Botanical Garden. Missouri Botanical Garden, Missouri, USA 2008. p. 3468

41. Prentice IC. Pollen representation, source area, and basin size: toward a unified theory of pollen analysis. Quaternary Research 1985;23(1):76-86.

42. Jato Rodríguez V, Iglesias Fernández I, Aira Rodríguez MJ. Allergen pollen atlas. Galicia, Spain; 1999. p. 245.

43. Baroni MV, Alvarez JS, Wunderlin DA, et al. Analysis of IgE binding proteins of Celtis tala pollen. Food and Agricultural Immunology. 2008;19(3):187-194.

44. Sieger R, Grobe H, Dieprenboek M. PanPlot - software to visualize profiles and core logs. Alfred Wegener Institute, Helmholtz Center for Polar and Marine Research, Bremerhaven, Germany; 2005.

45. Connel JT. Quantitative intranasal challenges. The priming effect in allergic rhinitis. J Allergy. 1969;43(1):33-44. 